\title{
The Atlantic Margin and the North Sea: Introduction
}

\author{
Hans Peeters, Fraser Sturt, and Kieran Westley
}

\begin{abstract}
The North Sea and Atlantic margins of Europe encompass a vast area of seabed and coastline, and a correspondingly large area of potential submerged landscape. This once-seamless landscape has been divided by modern political geography, leading to different research traditions, management regimes and, consequently, necessitating division into national summary chapters. This chapter presents a synthesis of the national summaries that follow by focusing on four common themes. Within each, we explore the variability and commonalities between countries. Firstly, we assess the overall archaeological and palaeoenvironmental evidence base. It is clear that the evidence is temporally deep, incorporates material ranging from in situ human footprints and wooden structures to derived and isolated lithic finds, contains indications of both aquatic and terres-
\end{abstract}

\footnotetext{
H. Peeters $(\bowtie)$

Groningen Institute of Archaeology, University of Groningen, Groningen, The Netherlands

e-mail: j.h.m.peeters@rug.nl

F. Sturt

Centre for Maritime Archaeology, University of

Southampton, Southampton, UK

e-mail: f.sturt@soton.ac.uk

K. Westley

School of Geography and Environmental Sciences, Ulster University, Coleraine, Northern Ireland, UK e-mail: kl.westley@ulster.ac.uk
}

trial activity, and can be found across the study area, albeit unevenly distributed, with a bias to the North Sea. Secondly, we examine preservation and discovery conditions. In addition to spatially variable taphonomy caused by regional geological, palaeoenvironmental (e.g. sea-level change, glaciation) and hydrodynamic conditions, there are also national differences in methods of investigation, notably the role of systematic investigation versus chance finds. Based on work done in the North Sea, thoughts are suggested as to possible methodological ways forward. Thirdly, we address the research potential of the wider region. Extant research frameworks have identified numerous common themes, but sub-regional themes also exist. In both cases, these may cross-cut existing borders and require transnational collaboration. Research potential also extends to a range of evidence types, including derived as well as in situ archaeology and palaeoenvironmental records. Finally, we look at the management context, highlighting the key role played by historic environment management and offshore industry in data collection and methodological advances. Overall, this synthesis demonstrates that much progress has been made, though concentrated in certain areas (e.g. the North Sea). Still more remains to be done, in terms of extending approaches to less-studied parts of the Atlantic margin but also in improving the quality of data collected. 


\section{Keywords}

Submerged prehistory $\cdot$ Submerged landscapes $\cdot$ North Sea $\cdot$ Atlantic margin . Intertidal

\subsection{Introduction}

The present-day Atlantic margin and North Sea basin represent marine environments with highly diverse characteristics in terms of hydrodynamics, seafloor and coastal geomorphology as well as sub-surface lithology (Cohen et al. 2017; Dawson et al. 2017; Farr et al. 2017; Westley and Edwards 2017). These result from an equally diverse set of interrelated geogenetic processes, driven by climate fluctuation and alternating palaeoenvironmental conditions. Cycles of Quaternary marine transgression and regression and accompanying variation in the balance of sedimentation versus erosion continuously rearranged the physical characteristics of these areas, sweeping from full terrestrial to full marine conditions and back. The dynamics of such processes were far from uniform; environmental change occurred on many different spatial and temporal scales, ranging from the supra-regional to local, and from the millennial to human lifetime (or generational) scale. Hence, the human occupation history and context of human behaviour in these now-submerged parts of the continental shelf can only be understood within the framework of these variable environmental dynamics. In fact, to come to an understanding of how prehistoric people interacted with the 'ebb and flow' of palaeoenvironmental dynamics in the (near-) coastal zone also involves a deeper understanding of the representativeness of the onshore terrestrial archaeological record. These are complementary sources of information.

In this section, we will develop a synthesis of the national chapters that are concerned with the Atlantic margin and North Sea basin: Ireland (Westley and Woodman, Chap. 11, this volume), Great Britain (Bailey et al., Chap. 10, this volume), Norway (Glørstad et al. Chap. 6, this volume), the Netherlands (Peeters and Amkreutz, Chap. 8, this volume), Belgium (Pieters et al., Chap. 9, this volume), the French (Billard et al., Chap. 12, this volume) and Spanish Atlantic margins (Arias, Chap. 13, this volume), and Portugal (Bicho et al. Chap. 14 , this volume). Our main objective is to explore and identify the background of the variable insights as presented in the national chapters, based on four themes. First, we will look at the actual evidence: archaeological finds, as well as palaeoenvironmental evidence, which is just as important for our understanding of prehistoric human behaviour as the artefacts left behind. Next, we address aspects of preservation and discovery in order to evaluate the significance of the known record. This in turn leads to further discussion of the area's research potential including identification of national and transnational research themes. Finally, we look at the management context, which involves the role of industry and institutions, as well as the maintenance of collections.

\subsection{Archaeological and Palaeoenvironmental Evidence}

The first thoughts about the potential importance of the submerged archaeological record date back to the nineteenth and early twentieth centuries, when observations of megalithic monuments below the high-water mark along the Atlantic margin indicated the presence of submerged cultural phenomena (Billard et al., Chap. 12, this volume). Similarly, observations of tree stumps in the intertidal zone along the British and Irish coasts provided evidence for drowned forests, which led to a first hypothetical reconstruction of the drowned landscape in the present-day North Sea (Reid 1913), now frequently referred to as 'Doggerland' (Coles 1998). The implications of these early observations of both submerged cultural and environmental remains are tremendous: they made, and make, clear that the archaeological record exposed on land today reflects the modern land/ sea boundary and not that seen in the past. This in turn impacted (and continues to impact) on how we interpret issues of connectivity and social interaction as they played out in the past. 
Now, more than a century later, the body of archaeological and palaeoenvironmental evidence from the Atlantic margin and North Sea has grown considerably. The national chapters make abundantly clear that this evidence consists of a wide array of phenomena, ranging from isolated objects deriving from unknown contexts, to undisturbed sites and palaeolandsurface remnants 'betraying' human presence in the form of footprints. However, the evidence presented is as variable between the national overviews as is the nature and dating of this evidence. Table 7.1 shows that the archaeological remains from the sub- and intertidal zones consist of artefacts made from diverse materials, as well as built structures, which functioned in settlement as well as ritual contexts. The built structures mostly date to the Neolithic or Bronze Age, whereas artefacts cover the Palaeolithic to Iron Age.

As far as can be derived from the inventories presented in the national chapters and descrip- tions provided in the SPLASHCOS Viewer (http://splashcos-viewer.eu/), it seems that the phenomena overwhelmingly relate to onshore activities, at least in the sense that the range of evidence is also known from onshore archaeological sites. As such, these phenomena represent submerged 'terrestrial' archaeology. For the Palaeolithic and Mesolithic, we are mostly dealing with lithic artefacts deriving from-most probably at least - the sort of settlement contexts known onshore. This is supported by research conducted on a few subtidal sites (Bouldnor Cliff; Rotterdam-Yangtze Harbour) off the British and Dutch coasts (Momber et al. 2011; Momber and Peeters 2017; Moree and Sier 2015; Peeters and Momber 2014). Examples dating to the Neolithic are various built structures, as observed in the intertidal zones along the coasts of the British Isles and France. The majority consist of megalithic monuments (tombs; menhirs), as well as wooden henges, which can be consid-

Table 7.1 Summary of archaeological evidence from the subtidal and intertidal zones of the Atlantic margin and North Sea, as presented in the national chapters

\begin{tabular}{|c|c|c|c|c|c|c|c|c|c|c|c|c|c|c|c|c|}
\hline & \multicolumn{2}{|c|}{ Ireland } & \multicolumn{2}{|c|}{\begin{tabular}{|l|} 
United \\
Kingdom \\
\end{tabular}} & \multicolumn{2}{|l|}{ Norway } & \multicolumn{2}{|c|}{ Netherlands } & \multicolumn{2}{|l|}{ Belgium } & \multicolumn{2}{|l|}{ France } & \multicolumn{2}{|l|}{ Spain } & \multicolumn{2}{|l|}{ Portugal } \\
\hline & $\begin{array}{l}\text { Stray/ } \\
\text { re- } \\
\text { worked }\end{array}$ & $\begin{array}{l}\text { In } \\
\text { situ }\end{array}$ & \begin{tabular}{|l} 
Stray/ \\
re- \\
worked
\end{tabular} & $\begin{array}{l}\text { In } \\
\text { situ }\end{array}$ & \begin{tabular}{|l} 
Stray/ \\
re- \\
worked
\end{tabular} & $\begin{array}{l}\text { In } \\
\text { situ }\end{array}$ & \begin{tabular}{|l|} 
Stray/ \\
re- \\
worked
\end{tabular} & \begin{tabular}{|l|} 
In \\
situ
\end{tabular} & \begin{tabular}{|l|} 
Stray/ \\
re- \\
worked
\end{tabular} & $\begin{array}{l}\text { In } \\
\text { situ }\end{array}$ & \begin{tabular}{|l|} 
Stray/ \\
re- \\
worked
\end{tabular} & \begin{tabular}{|l|} 
In \\
situ
\end{tabular} & \begin{tabular}{|l} 
Stray/ \\
re- \\
worked
\end{tabular} & \begin{tabular}{|l|} 
In \\
situ
\end{tabular} & $\begin{array}{l}\text { Stray/ } \\
\text { re- } \\
\text { worked }\end{array}$ & \begin{tabular}{|l|} 
In \\
situ
\end{tabular} \\
\hline $\begin{array}{l}\text { Faunal } \\
\text { remains }\end{array}$ & $\begin{array}{ll}\mathrm{PL} \\
\end{array}$ & & PL & & PL & & $\mathrm{PL} / \mathrm{M}$ & $\mathrm{M}$ & PL & & PL & \begin{tabular}{|l}
$\mathrm{PL} /$ \\
$\mathrm{H}$ \\
\end{tabular} & & & & \\
\hline $\begin{array}{l}\begin{array}{l}\text { Forest } \\
\text { remains }\end{array} \\
\end{array}$ & & $\mathrm{H}$ & & $\mathrm{P} / \mathrm{M}$ & & & $\mathrm{H}$ & & & & & $\mathrm{H}$ & & & & $\mathrm{M}$ \\
\hline $\begin{array}{l}\text { Animal } \\
\text { tracks }\end{array}$ & & & & $\mathrm{P} / \mathrm{M}$ & & & & & & & & & & & & \\
\hline $\begin{array}{l}\text { Human } \\
\text { footprints }\end{array}$ & & & & $\begin{array}{l}\mathrm{P} / \mathrm{M} \\
\mathrm{N}\end{array}$ & & & & & & & & $\mathrm{P} / \mathrm{N}$ & & & & \\
\hline $\begin{array}{l}\text { Fishing } \\
\text { structures }\end{array}$ & & $\mathrm{M}$ & & $\mathrm{N}$ & & & & & & & & $\mathrm{M} / \mathrm{N}$ & & & & \\
\hline $\begin{array}{l}\begin{array}{l}\text { Shell } \\
\text { middens }\end{array} \\
\end{array}$ & & & & M & & & & & & & & $\mathrm{N}$ & & & & M \\
\hline $\begin{array}{l}\text { Human } \\
\text { remains }\end{array}$ & $\mathrm{N}$ & & & $\begin{array}{l}\mathrm{M} / \\
\mathrm{N} / \\
\mathrm{LP}\end{array}$ & & & $\mathrm{P} / \mathrm{M} / \mathrm{LP}$ & & & & & & & & & M \\
\hline Burials & & & & $\mathrm{N}$ & & $\mathrm{M}$ & & & & & & $\mathrm{N}$ & & & & \\
\hline $\begin{array}{l}\text { Wooden } \\
\text { monuments }\end{array}$ & & & & $\overline{L P}$ & & & & & & & & & & & & \\
\hline $\begin{array}{l}\text { Megalithic } \\
\text { monuments }\end{array}$ & & $\mathrm{N}$ & & & & & & & & & & $\mathrm{N}$ & & & & \\
\hline $\begin{array}{l}\text { Ceramic } \\
\text { artefacts }\end{array}$ & & & & & & & & & LP & & & $\mathrm{N}$ & & & & $\begin{array}{l}\mathrm{N} / \\
\mathrm{LP} \\
\end{array}$ \\
\hline $\begin{array}{l}\text { Organic } \\
\text { artefacts }\end{array}$ & $\mathrm{M} / \mathrm{N}$ & & $\begin{array}{l}\mathrm{P} / \mathrm{M} / \mathrm{N} / \\
\mathrm{LP}\end{array}$ & \begin{tabular}{|l|}
$\mathrm{P} / \mathrm{M}$ \\
$\mathrm{N} /$ \\
$\mathrm{LP}$ \\
\end{tabular} & M & & $\mathrm{P} / \mathrm{M}$ & M & LP & & & $\mathrm{N}$ & & & & \\
\hline $\begin{array}{l}\text { Lithic } \\
\text { artefacts }\end{array}$ & $\mathrm{M} / \mathrm{N}$ & & $\begin{array}{l}\mathrm{P} / \mathrm{M} / \mathrm{N} / \\
\mathrm{LP}\end{array}$ & \begin{tabular}{|l|}
$\mathrm{P} / \mathrm{M}$ \\
$/ \mathrm{N} /$ \\
$\mathrm{LP}$
\end{tabular} & M & & $\mathrm{P} / \mathrm{M}$ & $\mathrm{M}$ & $\mathrm{P} / \mathrm{N}$ & & $\mathrm{P} / \mathrm{M} / \mathrm{N}$ & $\begin{array}{l}\mathrm{P} / \mathrm{M} / \\
\mathrm{N}\end{array}$ & & & & $\mathrm{P} / \mathrm{N}$ \\
\hline
\end{tabular}

PL Pleistocene, $H$ Holocene, $P$ Palaeolithic, $M$ Mesolithic, $N$ Neolithic, $L P$ Late Palaeolithic, Blue Subtidal, Pink Intertidal, Grey Subtidal or Intertidal, White No information 
ered as the 'organic' counterparts of megalithic henges.

However, this does not rule out evidence for an aquatic orientation of behaviour. Palaeolithic faunal assemblages, artistic depictions and stable isotope values from Cantabrian Spain provide evidence for the exploitation of the marine environment (Arias, Chap. 13, this volume). The numerous fish weirs (dating back at least to the Neolithic and possibly earlier) on the French Atlantic margin (Billard et al., Chap. 12, this volume) connect directly to the exploitation of aquatic resources, as do the North Wall Quay (Dublin) fish traps (Westley and Woodman, Chap. 11, this volume), possible remains of fish traps at Goldcliff, and intertidal shell middens at Westward Ho! on the British coast (Bailey et al., Chap. 10, this volume) and São Julião on the Portuguese coast (Bicho et al., Chap. 14, this volume). Finds at Bouldnor Cliff have been interpreted in connection with the possible making of canoes (Momber et al. 2011), a Neolithic logboat has been found in the intertidal zone of Strangford Lough (Westley and Woodman, Chap. 11, this volume) while boat use could be suggested by a possible wooden paddle from the Raversijde beach in Belgium (Pieters et al., Chap. 9, this volume). The remarkable finds of Middle Neolithic polished axe blades from the Brown Bank area in the Dutch sector of the North Sea also provide evidence for seafaring (as this area would have been flooded by this time), and possibly symbolic meaning of 'places' in a seascape (cf. Van de Noort 2011). The find of ritual depositions of axe blades in the intertidal zone of Brittany (Billard et al., Chap. 12, this volume) possibly connects to the symbolic meaning of the zone between land and water, and fits patterns of deposition found in onshore wetland environments all over NW Europe.

Of particular interest to the role of the shoreline are the human footprints found at various locations on the British and French coasts. Those at Happisburgh (Ashton et al. 2014; Bailey et al., Chap. 10, this volume) belong to multiple individuals (adults and children) and are among the scanty evidence for the earliest occupation of NW Europe $0.8-1$ million years ago. It is likely that shorelines played an important role in the colonisation of this part of the world by early humans (Cohen et al. 2012). Coastal exploitation is also evident from the Mesolithic and Neolithic footprints at Goldcliff (Bell 2007) and Formby (Huddart et al. 1999). Detailed analysis of these prints suggests age, and maybe, gender-related task division (Bailey et al., Chap. 10, this volume). The size of human footprints encountered at the fish-weir site of Saint-Jean-le-Thomas on the French coast-dating from the Neolithic to Bronze Age transition-shows the presence of children and adults (Billard and Bernard 2016). Information on age and gender-related task division can normally not be derived from material remains directly, where interpretations strongly depend on contextual information, or the interpretation of diet-related isotope data from human bones.

The footprints and animal tracks directly link humans to the environment, as individuals who crossed the landscape. We cannot get any closer to humans and animals moving in their environment than this. The aforementioned hypothesis on the submerged landscape in the present-day North Sea (Coles 1998; Reid 1913) is, in view of these 'snapshots', somewhat revolutionary. Observations of palaeoenvironmental phenomena - at the time of unknown age-triggered an idea about the physical layout of a forested landscape. The first archaeological finds reported from this submerged landscape came from the British and Dutch sectors of the North Sea and were of Mesolithic age (Louwe Kooijmans 1971). No more than a decade ago, the first images of palaeolandscape features became available, based on the analysis of 3D seismic data (Gaffney et al. 2007). However, as yet, little is known about how this landscape looked as a living environment, hosting diverse plant and animal communities, and indeed, humans. The 'Europe's Lost Frontiers Project' (Gaffney et al. 2017) is expected to provide important new data in this respect.

Nonetheless, submerged and intertidal landscapes, in particular the North Sea, have already delivered a vast body of palaeoenvironmental evidence. Analysis of high-resolution core sam- 
ples from the submerged site of RotterdamYangtze Harbour provided evidence for local human interference (clearance?) in wetland vegetation, possibly to permit movement between the settlement location on a sand dune and the nearby riverbank (Moree and Sier 2015, p. 307). Considerable quantities of mammalian remains dredged from the North Sea floor are most probably of Mesolithic age, and this is partly corroborated by radiocarbon dates (Glimmerveen et al. 2006). Most human remains from the North Sea also date to Mesolithic times, and stable isotope data indicate a diet consisting of terrestrial and freshwater foodstuffs (Van der Plicht et al. 2016). However, there seems to be little evidence for marine resources as important items of diet. In the perspective of the Mesolithic drowning history of the southern North Sea this might appear somewhat peculiar at first, but it might also suggest that the relationship between humans and (potential) environmental resources is more complicated. And returning to the footprints, what about socially differentiated diets?

Similar research is less well-developed outside the North Sea, though in some cases peat layers in the intertidal zones of the Atlantic margin have permitted insights into vegetational changes, mainly during the Holocene. One thing that is clear from the national chapters is that though submerged forests and organic layers are mostly known from the British coast, such palaeolandscape vestiges have in fact been encountered nearly everywhere. Thus the full potential of this evidence base away from the North Sea remains to be explored.

The environmental evidence is not limited to the Mesolithic and later prehistoric times, but extends well into the Palaeolithic, principally represented by mammal remains. Apart from incidental finds of Pleistocene mammals from the Atlantic margin and Channel area (Billard et al., Chap. 12, this volume; Westley and Woodman, Chap. 11, this volume), the overwhelming majority of finds originates from the North Sea (Glimmerveen et al. 2004, 2006; Mol et al. 2006). Bone assemblages consist of material dating to the Lower and Late Pleistocene; material securely dated to the Middle Pleistocene is less though certainly not absent (Cohen et al. 2017, p. 168). Since these finds were brought up in fishing nets, or derive from aggregate extraction, little is known about the original context. Targeted surveying during recent sand extraction off the Dutch coast, however, permitted insight into the stratigraphic origin of palaeontological material (Kuitems et al. 2015). One notable result concerns the establishment of a North Sea highstand during the early Weichselian (MIS 5d-a), based on mollusc evidence corroborated by OSL dates (Peeters and Amkreutz, Chap. 8, this volume). The importance of this finding is that it puts the AMS-based dates of sea mammals (e.g. Beluga, in Mol et al. 2006) in the Weichselian in a new perspective: it does make a difference whether sea levels were $70 \mathrm{~m}$ or $20 \mathrm{~m}$ lower than today when we consider archaeological issues, as the shoreline was positioned differently in the North Sea basin, and species like Beluga can be expected to have been present in parts of it.

Such insight is also crucial for our understanding of the human occupation of NW Europe during the Pleistocene. Handaxes and other flint artefacts come from various locations in the North Sea (Area 240; Middeldiep; Eurogeul: Bailey et al., Chap. 10, this volume; Peeters and Amkreutz, Chap. 8, this volume), submerged Middle Palaeolithic assemblages associated with faunal remains are documented off the Normandy and Armorican coast (Billard et al. Chap. 12, this volume), and intertidal Middle Palaeolithic assemblages are known from the Portuguese Atlantic coast (Bicho, Chap. 14, this volume). These too need to be placed in an appropriate palaeogeographic and palaeoenvironmental context if we are even to begin addressing questions of how past humans/hominins used this landscape and responded as it changed over time.

\subsection{Preservation and Discovery}

The summary above provides some insight into the range of archaeological and palaeoenvironmental evidence. The diversity of this evidence not only relates to variability in the occupation history of this vast region, but also to variability 
in taphonomy and discovery contexts. Long-term natural dynamics had drastic impact on the preservation of archaeological and palaeoenvironmental materials and layers. These dynamics also influence discovery potential. As succinctly highlighted by Bailey et al. (Chap. 10, this volume) in relation to intertidal forests, there is a delicate balance between preservation by burial and exposure by erosion to enable discovery. Modern economic exploitation of resources, most notably dredging and bottom trawling, can also lead to erosion of sedimentary layers and removal of archaeological material or palaeoenvironmental evidence from its stratigraphic context. The specific technology involved largely determines which materials can potentially be discovered, whereas the involvement of individuals with variable knowledge about remains of archaeological or palaeoenvironmental interest determines which materials are actually collected. In order to make the evidence meaningful for ongoing research, to assess the research potential and define research themes, it is therefore important to take a closer look at these factors.

Table 7.2 shows that surveys and controlled research result in relatively few discoveries, and these are best represented in Great Britain and France. Taking the study area as a whole, the discovery of finds by chance in fishing nets and on waste piles at wharves outnumbers discoveries resulting from systematic work. Trends are, however, not the same for the listed nations, and many factors may underlie the differences. Erosion of the steeper parts of the British and French coast exposes archaeological sites that can readily be accessed and investigated in the intertidal and subtidal zone. In contrast, prehistoric levels along the gently sloping Dutch and Belgian coast are covered with metres of sediment. Water depth and visibility are also factors to keep in mind, as are traditional foci of interest, notably shipwrecks, among sports divers and professionals alike.

Aspects of erosion and sedimentation are, however, of prime importance with regard to preservation and discovery potential. Ward and Larcombe (2008) have proposed a conceptual framework for the assessment of geomorphological structures and lithological units in terms of archaeological potential. This is useful at a scale when more detailed information is available about the geological structure below the seafloor (Peeters and Momber 2014; Cohen et al. 2017). At a coarser scale, it remains worthwhile to bear in mind the general trends in the geological development of (parts of) sea basins. The southern and central North Sea, for instance, is to a large extent a subsiding basin with an infill of hundreds of metres of vertically stacked Quaternary sediments. This leaves room for an accumulation of archaeologically relevant strata, covering at least the entire time span for which we possess evidence of human presence in NW Europe. Conversely, areas on the 'shoulders' of the basin, where subsidence is minimal or absent exhibit greater stratigraphic complexity, with

Table 7.2 Overview of discovery contexts and their relative degree of application: incidental $(+)$, occasional $(++)$, frequent (+++)

\begin{tabular}{|c|c|c|c|c|c|c|c|}
\hline \multirow[b]{2}{*}{ Nation } & \multicolumn{3}{|c|}{ Chance finds } & \multicolumn{2}{|l|}{ Surveys } & \multicolumn{2}{|c|}{ Controlled research } \\
\hline & Exposure & Dredging & Trawling & $\begin{array}{l}\text { Grab } \\
\text { sampling }\end{array}$ & $\begin{array}{l}\text { Targeted } \\
\text { fishing }\end{array}$ & $\begin{array}{l}\text { Visual } \\
\text { assessment }\end{array}$ & Excavation \\
\hline Ireland & + & + & & & & + & + \\
\hline $\begin{array}{l}\text { Great } \\
\text { Britain }\end{array}$ & +++ & ++ & + & ++ & & ++ & ++ \\
\hline Norway & & + & & & & + & + \\
\hline Netherlands & & +++ & +++ & & ++ & & + \\
\hline Belgium & & + & + & & & & \\
\hline France & +++ & & ++ & & & ++ & ++ \\
\hline Spain & + & + & & & & + & \\
\hline Portugal & + & & & & & + & ++ \\
\hline
\end{tabular}


highstand deposits of multiple ages superimposed at broadly the same level. The lack of subsidence in these areas also makes them more prone to erosion, exemplified by the exposure of Lower Palaeolithic levels (including the key early sites of Pakefield and Happisburgh) on the eastern coast of Britain (Cohen et al. 2017).

Similarly, erosive regimes on the Atlantic margin do not necessarily imply absence of archaeological remains. Without doubt, largescale erosion in the Channel/La Manche due to catastrophic Pleistocene flooding events (Gupta et al. 2007) swept away parts of older landscape structures and their associated archaeology. In other parts, old sediment layers will have survived, whilst new sediment layers may have been deposited (and may have been eroded afterwards). The Middle Palaeolithic sites on the Armorican and Normandy coast (Billard et al., Chap. 12, this volume), as well as on the Spanish and Portuguese coasts (Arias, Chap. 13, this volume; Bicho et al., Chap. 14, this volume) emphasise the interest and importance of palaeoshorelines. At the same time, we must bear in mind that shorelines are vulnerable to erosion, particularly so when sediment supply is limited, coasts are steep and wave fetch is large. Conceptually at least, this would appear to rule out large parts of Europe's Atlantic-facing coast as likely to preserve submerged prehistoric sites and would seem to be borne out by the overall site distribution shown in the SPLASHCOS viewer. Clearly, there are many more sites clustered within the North Sea compared to the open Atlantic margin.

However, this is not to say that such zones are of no interest. Local conditions, such as protected bays and inlets, like the ones encountered along the Irish, Norwegian and French Atlantic coasts (Billard et al., Chap. 12 this volume; Glørstad et al., Chap. 6 this volume; Westley and Woodman, Chap. 11, this volume), may have favoured preservation of archaeological and palaeoenvironmental remains. Hence, the potential presence of such 'capsules' is important because of the possibilities it offers to collect at least tiny pieces of the puzzle, and to gain some idea of what is missing. These same issues apply to the erosive impact of glaciation, often seen as resulting in the removal or reworking of the archaeological record. Within the North Sea and Atlantic margin, notwithstanding potential limits to hominin environmental tolerances, this may be a contributing factor to the lack of a pre-Last Glacial Maximum (LGM) record in regions most strongly affected by glaciation: Scandinavia, northern Britain and Ireland. However, glacial removal of evidence is not universal, as exemplified by preservation of Lower Palaeolithic/Cromerian deposits under water-laid glacial sediments in eastern England or even the role of glacial depressions (e.g. tunnel valleys, kettle holes) in which postglaciation sediment can accumulate (Cohen et al. 2017).

From this, it follows that geoarchaeological assessment of any area under consideration is a first step. We simply cannot rely on the generally coarse subsurface models available. As outlined in the 'North Sea Prehistory Research and Management Framework' (NSPRMF; Peeters et al. 2009, p. 11), we find ourselves confronted with a high level of perceived need for data, and in connection with this a high level of risk/fear of making significant mistakes. In order to lower these levels of uncertainty, there is need for more secure data points, which will improve the value of data in general and the models built on it. Hence, there is a critical need for testing geoarchaeological models of site preservation. Paradoxically, invasive economic activities provide opportunities for such model testing (Peeters et al. 2009, p. 11). However, one such activity, which provided a major source of information until recently, is now legally prohibited EU-wide: beam trawling (see also Maarleveld, Chap. 25, this volume). As a result, the fishing industry can no longer make a contribution to resolving the aforementioned problem. This is all the more unfortunate, since it has become clear that targeted fishing for palaeontological remains-and why not archaeological remains for that matteris promising (Mol 2012).

Discovery potential remains an aspect that requires continuous attention. Which strategies and technologies are chosen for the detection of archaeological remains is (partly) one of the 
national traditions. In the Netherlands, onshore strategies strongly rely on core sampling in the survey stage of investigations. In a next step, extensive coring and/or test pitting is conducted to assess potential significance and subsequent decision-making. This approach has been translated to the offshore environment and executed in the context of the Rotterdam harbour extension, although here it was preceded by seismic profiling of the subsurface (Vos et al. 2015). The strategy proved to be successful, since a Mesolithic site was discovered. Subsequent stratigraphically controlled grab sampling delivered interesting results (Moree and Sier 2015; Peeters and Amkreutz, Chap. 8, this volume), but given the rather low quantities of finds, the discovery of some flint knapping debris and burnt bone in a core must be considered a lucky strike.

Despite the fact that systematic grab sampling is more destructive than core sampling, its chances of finding archaeological remains are better, if the artefact-bearing layers are located at, or near the seabed surface. Such an approach has shown its success in the case of Area 240 in British waters (Tizzard et al. 2015). Clearly, sample size (in terms of the grab sampler capacity) and sample density on the seabed are critical factors when it comes to the detection of archaeological sites (Wessex Archaeology 2008). At the same time, however, it is important to be able to put finds in a stratigraphical and palaeoenvironmental context - and this is where grab sampling is inherently limited-otherwise we are left with collections of items which have restricted information value. Hence, it appears that a combined approach to the problem bears the best chances of delivering quality data and will move us forward in steps which are successively refined in focus based on previous results (e.g. Vos et al. 2015). Geophysical techniques provide possibilities to map the seabed and subsurface, and in combination with coring information, permit geoarchaeological models, which can be tested by means of grab sampling. In a next stage, high-quality core sampling can focus on the collection of palaeoenvironmental and fine-grained stratigraphical data. In a final stage, targeted and controlled grab sampling, or perhaps if conditions are conducive, diver-led sampling, can be conducted to obtain quality data on the archaeology.

\subsection{Research Potential and Themes}

The range of archaeological phenomena discussed in the national chapters for the Atlantic margin and North Sea mirrors a myriad of underlying behaviours. This, in itself, demonstrates a high research potential. As discussed, preservation conditions and discovery potential are diverse at variable spatial scales. This has implications for the research potential in various parts of the Atlantic margin and North Sea Basin.

For the (southern) North Sea, the NSPRMF identifies several research themes and topics (Table 7.3). The scientific background for this document (Peeters et al. 2009), which resulted from a joint effort of researchers and heritage professionals to define a common perspective on the problem of submerged prehistoric archaeology in the sector (Salter et al. 2014), was published as a special volume of the 'Netherlands Journal of Geosciences' (Peeters and Cohen 2014). Furthermore, a national maritime archaeological research agenda exists for English waters, which outlines many similar research themes (Ransley and Sturt 2013).

All themes and topics are still relevant in the current state of affairs. In consideration of the archaeological evidence, the same (or at least very similar) themes and topics are equally applicable to the Atlantic margin. The focus on the Palaeolithic and Mesolithic can easily be expanded to later prehistoric times. Also, there is room for (sub-) regional differentiation, through inclusion of specific research topics. For instance, evidence from the Norwegian coast would lend itself to discussion of postglacial colonisation of new landscapes by sea, while evidence from around the western seaways of the British Isles would be conducive to addressing questions surrounding the nature of Mesolithic and Neolithic networks and connections between Great Britain, Ireland, mainland Europe and smaller outlying island groups (e.g. the Western Isles, Scilly Isles, Isle of Man). 
Table 7.3 Research themes and topics from the NSPRMF (Peeters et al. 2009). Despite the fact that theme G primarily focusses on post-LGM hunter-gatherers, topic G.2 is broadly defined, and is of equal relevance to theme D

\begin{tabular}{|c|c|}
\hline Theme & Topics \\
\hline \multirow{4}{*}{$\begin{array}{l}\text { A. Stratigraphic and chronological } \\
\text { frameworks }\end{array}$} & A.1: Lithostratigraphic classification and chronological anchoring \\
\hline & A.2: Sea level change and glacio-isostacy \\
\hline & A.3: Survival of deposits of archaeological significance \\
\hline & A.4: Biostratigraphies and absolute dating \\
\hline \multirow[t]{4}{*}{ B. Palaeogeography and environment } & B.1: Middle/Late Pleistocene reshaping of topography and river drainage \\
\hline & B.2: Development of the Weichselian/Devensian landscape \\
\hline & B.3: Palaeogeographic evolution after the Last Glacial Maximum (LGM) \\
\hline & B.4: Quaternary palaeoecology \\
\hline \multirow{2}{*}{$\begin{array}{l}\text { C. Global perspectives on } \\
\text { intercontinental hominin dispersals }\end{array}$} & C.1: North Sea coastal dynamics and human uses of the coastal zone \\
\hline & C.2: Pleistocene North Sea level oscillations and population of islands \\
\hline \multirow{2}{*}{$\begin{array}{l}\text { D. Pleistocene hominin colonisations of } \\
\text { northern Europe }\end{array}$} & D.1: Early human exploitation strategies in changing environments \\
\hline & D.2: Natural barriers for hominin expansion \\
\hline \multirow{2}{*}{$\begin{array}{l}\text { E. Reoccupation of northern Europe } \\
\text { after the Last Glacial Maximum (LGM) }\end{array}$} & E.1: Post-LGM occupation flux \\
\hline & E.2: Occupation strategies \\
\hline \multirow{3}{*}{$\begin{array}{l}\text { F. Post-glacial land use dynamics in the } \\
\text { context of a changing landscape }\end{array}$} & F.1: Changing landscape structure \\
\hline & F.2: Behavioural diversity among hunter-gatherers \\
\hline & F.3: Maritime archaeologies of the North Sea \\
\hline \multirow{3}{*}{$\begin{array}{l}\text { G. Representation of prehistoric } \\
\text { hunter-gatherer communities and } \\
\text { lifeways }\end{array}$} & G.1: Spatial perspectives on North Sea palaeolandscapes \\
\hline & G.2: The distributional nature of early hominin communities \\
\hline & G.3: Enculturated hunter-gatherer landscapes \\
\hline
\end{tabular}

The brief review presented above makes clear that there exist several transnational topics, which offer potential opportunities to develop joint research programmes. One such topic concerns the role of individuals in the exploitation of the coastal zone. The discovery of human footprints from various periods along the British and French coast permits us to gain unique insights into the presence of individuals of different age and physical condition, who spent time on the intertidal mudflats for various purposes. This information source is highly vulnerable to erosion, which is expected to increase with climate change and rising sea levels. Joining forces to develop ways to safeguard this information rapidly and effectively is crucial. In addition, how can further information about these individuals, and the environments wherein they operated, be extracted? For instance, what are the possibilities for sedaDNA analysis? After all, the fact that such imprints are preserved in the first place means that they were rapidly covered with a protecting layer of sediment; and this may have been favourable for the preservation of DNA.
The potential for archaeological and palaeoenvironmental research of in situ contexts appears to be most favourable in the intertidal zone. Subtidal contexts are more difficult to identify and investigate, notably in deep water. Where potentially important layers are expected at some depth below the seafloor, the situation is even more complicated. This is not to say that highresolution excavation underwater is not possible. The work at Bouldnor Cliff in British waters makes a good example (Momber et al. 2011; Bailey et al., Chap. 10, this volume). However, it is also clear that underwater excavation comes with restrictions on the spatial extent of investigations. High-resolution data will provide information on small sections of sites, the greatest part of which cannot be investigated. Hence, the question of representativeness is highly relevant-as it is onshore. The design of smart strategies is therefore critical, but in helping to move the discipline forward we may have to accept some initial loss of information compared to the possibilities for data collection onshore.

It is equally important to bear in mind that finds from less well documented-or even com- 
pletely undocumented-contexts carry intrinsic information of potential scientific importance. A good example is the combined use of radiocarbon dates and stable isotope data to draw inferences about diet from Mesolithic human remains from the North Sea (Van der Plicht et al. 2016). Initial results from DNA analysis of bone samples from the North Sea also appear promising (Dr Luc Amkreutz, pers. comm.). Hence, scientifically valuable data can be extracted from individual finds even when the original context is unknown.

Similarly, such data can also provide a starting point for new research. Radiocarbon dating of Pleistocene mammal remains, for instance, demands a critical approach to methodology and sampling. Busschers et al. (2014) were able to show that molluscs securely dated to the Eemian (MIS 5: $>75 \mathrm{ka}$ ) based on multi-proxy data (biostratigraphy; lithostratigraphy; OSL and U-Th dating; age-depth relations to sea level), return radiocarbon ages where they should not, given the technique's $\sim 50 \mathrm{ka}$ limit. This appears to result from the effects of the secondary introduction of carbonate, due to bacterial activity, which caused inter-crystalline secondary carbon precipitation. This raises the question to what extent radiocarbon dates obtained on Pleistocene mammal bones dredged from the North Sea floor are reliable (Busschers et al. 2014, p. 1162). There is no fundamental reason to doubt the validity of such dates for remains of animals ('cold fauna') which are known to have roamed the Weichselian landscape. However, in other cases problems arise. For instance, the claimed Weichselian age for the remains of a sabre-toothed cat (Mol et al. 2006, 2008), which was long believed to have become extinct at c. $300 \mathrm{ka}$, is surprising. Is there a possibility that the obtained date is a result of taphonomic contamination? Along the same lines, obtained dates on fauna that seem to fit a potentially correct age (e.g. woolly mammoth, c. $40 \mathrm{ka}$ ) are not necessarily reliable.

Obtaining insights into the age and time-depth of palaeontological bone assemblages is of direct archaeological significance. On the one hand, such information provides an important building block for our understanding of Pleistocene envi- ronments in which various hominin species lived, whilst on the other hand it paves the way for the development of new ideas and hypotheses. For instance, the vast quantity of mammoth remains dredged from the Dutch seafloor has led to ideas about the behaviour and mortality of these animals from a palaeontological perspective (Mol 2012). The same finds have made others hypothesise about the potential presence of Early Upper Palaeolithic mammoth hunting and construction of dwellings from mammoth bones, similar to those found in Eastern Europe (Grøn 2015). In both cases, insight into the chronological integrity of assemblages becomes important. The improvement of compound AMS dating opens new directions for shedding light on such matters.

From this it follows that the submerged evidence from the Atlantic margin and North Sea basin has an enormous research potential. The range of research themes and topics is wide, and addresses issues of diverse nature (archaeology; palaeontology; palaeolandscape; taphonomy; methodology). From a purely quantitative perspective, the body of evidence known and potentially present is not the problem. More important is the question as to how to make the most out of this evidence, and in which ways we can improve the possibilities to collect qualitatively sound sets of materials and data, which can be fully connected to and interpreted in the context of the onshore record that we are used to working with, and which dominates archaeological models of the human past.

\subsection{Industry, Institutions and Collections}

One of the key points which can be drawn both from the national summaries and the recent literature (e.g. Benjamin et al. 2011; Evans et al. 2014; Bailey et al. 2017; Flemming et al. 2017) is that submerged prehistory is now well-accepted across the region. We are now beyond Coles' (1998) 'speculative survey'. While there are still considerable gaps in our knowledge of submerged landscapes, concerted efforts have been made, or are in progress, to fill these. 
Importantly, this acceptance and willingness to engage with the submerged record is not just purely research-led. Crucially, submerged prehistory is now an intrinsic part of cultural resource/ historic environment management, hence is included within coastal and offshore licencing or environmental impact assessment regimes (e.g. Sturt et al. 2017, for England; see also Pater, Chap. 27, this volume), or at least steps are underway to include within national regulatory and management frameworks (e.g. Missiaen et al. 2017, for Belgium). This is important since it is largely through major offshore industry projects that the vast majority of seabed activity takes place. With the exception of a handful of researchled projects (e.g. Europe's Lost Frontiers Project: Gaffney et al. 2017), these are the only approaches with the finances capable of acquiring the extensive seabed and sub-seabed geophysical and geotechnical data required to build the detailed geoarchaeological models described above. Therefore, it should be no surprise that some of the biggest advances of the last decade have come through this engagement. Examples are the 3D-seismic-based reconstructions of the southern North Sea (Gaffney et al. 2007, 2009; Van Heteren et al. 2014), the Area 240 finds and follow-up survey (Tizzard et al. 2011, 2015), and most recently the Rotterdam Harbour Mesolithic investigations (Moree and Sier 2015). Even at a much smaller scale, the national summaries provide examples of material identified via commercial/pre-development investigation, such as the North Wall Quay fish traps (Westley and Woodman, Chap. 11, this volume) and finds from western Norway (Glørstad et al., Chap. 6, this volume).

Given the potential spatial and temporal extent of the submerged prehistoric record of the North Sea and Atlantic Margin, and the transnational nature of many of the potential sedimentary deposits of interest, it is imperative that this engagement is maintained both nationally and internationally if the discipline is to progress. It is, however, also important to ensure that engagement does not stand still, and that existing 'best practice' approaches do not become fixed. If available, innovative approaches and technolo- gies should be introduced to improve the data collected (thus enabling more 'good' data points as described above) and to start addressing new questions as they come up (see also Peeters et al. 2009; Ransley and Sturt 2013). Despite the importance of results presented in the national chapters, it will be necessary to find ways to get a tighter grip on the archaeology that is actually resting on and under the seafloor. As noted, Coles' (1998) speculations have turned into evidence-based models of potential, underpinned with a handful of concrete archaeological observations. Now, we should engage in targeted attempts to turn these models of potential into archaeological realities.

\section{References}

Ashton N, Lewis SG, De Groote I, Duffy SM, Bates M, Bates R, Hoare P, Lewis M, Parfitt SA, Peglar S, Williams C, Stringer C (2014) Hominin footprints from Early Pleistocene deposits at Happisburgh, UK. PLoS ONE 9(2):e88329. https://doi.org/10.1371/ journal.pone.0088329

Bailey GN, Harff J, Sakellariou D (2017) Under the sea: archaeology and palaeolandscapes of the continental shelf. Springer, Cham

Bell M (2007) Prehistoric coastal communities: the Mesolithic in Western Britain. CBA research report 149. Council for British Archaeology, York

Benjamin J, Bonsall C, Pickard C, Fischer A (eds) (2011) Submerged prehistory. Oxbow, Oxford

Billard C, Bernard V (2016) Pêcheries de Normandie: Archéologie et histoire des pêcheries littorales du département de la Manche. Presses Universitaires de Rennes, collection Archéologie et Culture, Rennes

Busschers FS, Wesselingh FP, Kars RH, Versluijs-Helder M, Wallinga J, Bosch JHA, Timmer J, Nierop KGJ, Meijer T, Bunnik FPM, De Wolf H (2014) Radiocarbon dating of Late Pleistocene marine shells from the southern North Sea. Radiocarbon 56(3):1151-1166

Cohen KM, MacDonald K, Joordens JCA, Roebroeks W, Gibbard PL (2012) Earliest occupation of north-west Europe: a coastal perspective. Quatern Int 271:70-83

Cohen KM, Westley K, Erkens G, Hijma MP, Weerts HTJ (2017) The North Sea. In: Flemming NC, Harff J, Moura D, Burgess A, Bailey G (eds) Submerged landscapes of the European continental shelf. Quaternary paleoenvironments. Wiley-Blackwell, Chichester, pp 147-186

Coles BJ (1998) Doggerland: a speculative survey. Proc Prehist Soc 64:45-81

Dawson S, Bates R, Wickham-Jones C, Dawson A (2017) Northern North Sea and Atlantic Northwest 
approaches. In: Flemming NC, Harff J, Moura D, Burgess A, Bailey GN (eds) Submerged landscapes of the European continental shelf: quaternary paleoenvironments. Wiley, Chichester, pp 187-209

Evans A, Flatman J, Flemming N (eds) (2014) Prehistoric archaeology on the continental shelf. A global review. Springer, Dordrecht

Farr RH, Momber G, Satchell J, Flemming N (2017) Paleolandscapes of the Celtic Sea and the Channel/ La Manche. In: Flemming NC, Harff J, Moura D, Burgess A, Bailey G (eds) Submerged landscapes of the European continental shelf: quaternary paleoenvironments. Wiley-Blackwell, Chichester, pp 211-241

Flemming NC, Harff J, Moura D, Burgess A, Bailey GN (eds) (2017) Submerged landscapes of the European continental shelf: quaternary paleoenvironments. Wiley, Chichester

Gaffney V, Thomson K, Fitch S (eds) (2007) Mapping Doggerland: the Mesolithic landscapes of the southern North Sea. Archaeopress, Oxford

Gaffney V, Fitch S, Smith D (2009) Europe's Lost World, the rediscovery of Doggerland, CBA research report 160. Council for British Archaeology, York

Gaffney V, Allaby R, Bates R, Bates M, Ch'ng E, Fitch S, Garwood P, Momber G, Murgatroyd P, Pallen M, Ramsey E, Smith D, Smith O (2017) Doggerland and the Lost Frontiers Project (2015-2020). In: Bailey GN, Harff J, Sakellariou D (eds) Under the sea: archaeology and palaeolandscapes of the continental shelf. Springer, Cham, pp 305-319

Glimmerveen J, Mol D, Post K, Reumer JWF, Van der Plicht H, De Vos J, Van Geel B, Van Reenen G, Pals JP (2004) The North Sea project: the first palaeontological, palynological, and archaeological results. In: Flemming NC (ed) Submarine prehistoric archaeology of the North Sea: research priorities and collaboration with industry. CBA research report 141. Council for British Archaeology, York, pp 43-52

Glimmerveen J, Mol D, Van der Plicht J (2006) The Pleistocene reindeer of the North Sea - initial palaeontological data and archaeological remarks. Quatern Int 142/143:242-246

Grøn O (2015) A potential for submerged Late Weichselian mammoth-hunter sites in the Scandinavian North Sea sector? https://www.academia.edu/15411538/

Gupta S, Collier JS, Palmer-Felgate A, Potter G (2007) Catastrophic flooding origin of shelf valley systems in the English Channel. Nature 448:342-346

Huddart D, Roberts G, Gonzalez S (1999) Holocene human and animal footprints and their relationship with coastal environmental change, Formby Point, NW England. Quatern Int 55:29-41

Kuitems M, Van Kolfschoten T, Busschers F, De Loecker D (2015) Geoarchaeological and palaeontological research in the Maasvlakte 2 sand extraction zone and on the artificially created Maasvlakte 2 beach: a synthesis. In: Moree JM, Sier MM (eds) Interdisciplinary research programme Maasvlakte 2. Rotterdam. BOOR, Rotterdam, pp 351-398
Louwe Kooijmans LP (1971) Mesolithic bone and antler implements from the North Sea and from the Netherlands. Berichten Rijksdienst voor het Oudheidkundig Bodemonderzoek 20(21):27-73

Missiaen T, Pieters M, Maes F, Kruiver P, De Maeyer P, Seys J (2017) The SeArch project: towards an assessment methodology and sustainable heritage policy for the archaeological heritage of the North Sea in Belgium. In: Bailey GN, Harff J, Sakellariou D (eds) Under the sea: Archaeology and palaeolandscapes of the continental shelf. Springer, Cham, pp 415-424

Mol D (2012) Two days of trawling in the Eurogully: Did trawler OD7 find a mammoth graveyard? Dep Mag 30:13-15

Mol D, Post K, Reumer JWF, Van der Plicht J, De Vos J, Van Geel B, Van Reenen G, Pals J-P, Glimmerveen J (2006) The Eurogeul - first report of the palaeontological, palynological and archaeological investigations of this part of the North Sea. Quater Int 142/143:178-185

Mol D, De Vos J, Van Geel B, Glimmerveen J, Van der Plicht J, Post K (2008) Mammoeten, neushoorns en andere dieren van de Noordzeebodem. Kleine encyclopedie van het leven in het Pleistoceen. Veen Magazines, Diemen

Momber G, Peeters H (2017) Postglacial human dispersal and submerged landscapes in North-west Europe. In: Bailey GN, Harff J, Sakellariou D (eds) Under the sea: Archaeology and palaeolandscapes of the continental shelf. Springer, Cham, pp 321-334

Momber G, Tomalin D, Scaife R, Satchell J, Gillespie J (eds) (2011) Mesolithic occupation at Bouldnor Cliff and the submerged prehistoric landscapes of the Solent. CBA research report 164. Council for British Archaeology, York

Moree JM, Sier MM (2015) Twenty meters deep! The Mesolithic period at the Yangtze Harbour site Rotterdam Maasvlakte, the Netherlands. Early Holocene landscape development and habitation. In: Moree JM, Sier MM (eds) Interdisciplinary research programme Maasvlakte 2, Rotterdam. BOOR, Rotterdam, pp 7-350

Peeters JHM, Cohen KM (eds) (2014) North Sea submerged landscapes and prehistory. Geology, prehistoric archaeology and research potential of the southern North Sea. Netherlands J Geosci 93(1/2):3-6

Peeters JHM, Momber G (2014) The southern North Sea and the human occupation of northwest Europe after the Last Glacial Maximum. Netherlands J Geosci 93(1/2):55-70

Peeters H, Flemming N, Murphy P (eds) (2009) North Sea Prehistory Research and Management Framework (NSPRMF). Rijksdienst voor het Cultureel Erfgoed, Amersfoort

Ransley J, Sturt F (eds) (2013) People and the sea: a maritime archaeological research agenda for England. CBA research report 171. Council for British Archaeology, York

Reid C (1913) Submerged forests. Cambridge University Press, Cambridge 
Salter E, Murphy P, Peeters H (2014) Researching, conserving and managing submerged prehistory: national approaches and international collaboration. In: Evans A, Flatman J, Flemming N (eds) Prehistoric Archaeology on the Continental Shelf. A global review. Springer, Dordrecht, pp 151-172

Sturt F, Dix J, Grant MJ (2017) The history of industrylinked research in English waters: lessons for the future. In: Bailey GN, Harff J, Sakellariou D (eds) Under the sea: archaeology and palaeolandscapes of the continental shelf. Springer, Cham, pp 425-436

Tizzard L, Baggaley PA, Firth AJ (2011) Seabed prehistory: investigating palaeolandsurfaces with Palaeolithic remains from the southern North Sea. In: Benjamin J, Bonsall C, Pickard C, Fischer A (eds) Submerged prehistory. Oxbow, Oxford, pp 65-74

Tizzard L, Bicket AR, de Loecker D (2015) Seabed prehistory: investigating the palaeogeography and Early Middle Palaeolithic archaeology in the southern North Sea. Wessex Archaeology Report 35. Wessex Archaeology, Salisbury

Van de Noort R (2011) North Sea archaeologies. A maritime biography 10,000BC - AD 1500. Oxford University Press, Oxford

Van der Plicht J, Amkreutz L, Niekus MJLT, Peeters H, Smit B (2016) Surf ' $n$ Turf in Doggerland: Dating, stable isotopes and diet of Mesolithic human remains from the southern North Sea. J Archaeol Sci Rep 10:110-118

Van Heteren S, Meekes JAC, Bakker MAJ, Gaffney V, Fitch S, Gearey BR, Paap BF (2014) Reconstructing North Sea palaeolandscapes from 3D and high-density 2D seismic data: an overview. Netherlands J Geosci 93(1/2):31-42

Vos PC, Bunnik FPM, Cohen KM, Cremer H (2015) A staged geogenetic approach to underwater archaeological prospection in the Port of Rotterdam (Yantzehaven, Maasvlakte, the Netherlands): a geological and palaeoenvironmental case study for local mapping of Mesolithic lowland landscapes. Quatern Int 367:4-31

Ward I, Larcombe P (2008) Determining the preservation rating of submerged archaeology in the post-glacial southern North Sea: a first-order geomorphological approach. Environ Archaeol 13:59-83

Wessex Archaeology (2008) Seabed in prehistory: gauging the effects of marine aggregate dredging. Final report, volume I-VIII, ref. Wessex Archaeology, Salisbury, p 57422

Westley K, Edwards R (2017) Irish Sea and Atlantic margin. In: Flemming NC, Harff J, Moura D, Burgess A, Bailey GN (eds) Submerged landscapes of the European continental shelf: Quaternary paleoenvironments. Wiley, Chichester, pp 241-280

Open Access This chapter is licensed under the terms of the Creative Commons Attribution 4.0 International License (http://creativecommons.org/licenses/by/4.0/), which permits use, sharing, adaptation, distribution and reproduction in any medium or format, as long as you give appropriate credit to the original author(s) and the source, provide a link to the Creative Commons licence and indicate if changes were made.

The images or other third party material in this chapter are included in the chapter's Creative Commons licence, unless indicated otherwise in a credit line to the material. If material is not included in the chapter's Creative Commons licence and your intended use is not permitted by statutory regulation or exceeds the permitted use, you will need to obtain permission directly from the copyright holder. 